Article

\title{
Steroids from Marine-Derived Fungi: Evaluation of Antiproliferative and Antimicrobial Activities of Eburicol
}

Ana Camila Dos Santos Dias ${ }^{1}$, Aurélie Couzinet-Mossion ${ }^{1} \mathbb{D}$, Nicolas Ruiz ${ }^{1} \mathbb{D}$, Fatima Lakhdar ${ }^{2}$, Samira Etahiri ${ }^{2}$, Samuel Bertrand ${ }^{1}$ (D) Lucie Ory ${ }^{1}$, Christos Roussakis ${ }^{3}$, Yves François Pouchus ${ }^{1}$, El-Hassane Nazih ${ }^{1}$ and Gaetane Wielgosz-Collin ${ }^{1, *}$

1 Faculty of Pharmacy, University of Nantes, MMS-EA2160; 9, Rue Bias, 44000 Nantes, France; acamiladias@gmail.com (A.C.D.S.D.); aurelie.couzinet-mossion@univ-nantes.fr (A.C.-M.); nicolas.ruiz@univ-nantes.fr (N.R.); samuel.bertrand@univ-nantes.fr (S.B.);

lucie.ory@etu.univ-nantes.fr (L.O.); yves-francois.pouchus@univ-nantes.fr (Y.F.P.); el-hassane.nazih@univ-nantes.fr (E.-H.N.)

2 Laboratory of Marine Biotechnology and Environment, Faculty of Science, University Chouaib Doukkali, BP 20 El Jadida, Morocco; fatima19862008@hotmail.fr (F.L.); setahiri@hotmail.com (S.E.)

3 Faculty of Pharmacy, University of Nantes, IICiMed, 9, Rue Bias, 44000 Nantes, France; christos.roussakis@univ-nantes.fr

* Correspondence: gaetane.wielgosz-collin@univ-nantes.fr; Tel.: +33-276-645-081

Received: 13 May 2019; Accepted: 19 June 2019; Published: 21 June 2019

check for updates

\begin{abstract}
The most common sterol in fungi is ergosterol, which has frequently been investigated in human pathogenic fungal strains. This sterol, and others isolated from fungal strains, has also demonstrated cytotoxicity against cancer cell lines and antimicrobial activities. Marine fungi can produce high amounts of bioactive compounds. So, a screening was performed to study sterol composition using GC/MS in 19 marine fungal strains and ergosterol was always the major one. One strain, Clonostachys rosea MMS1090, was selected due to its high amount of eburicol and a one strain many compounds approach was performed on seven culture media to optimize its production. After purification and structural identification by NMR, eburicol was assessed against four cancer cell lines, MCF-7, MDA-MB-231, NSCLC-N6-L16 and A549, and seven human pathogenic bacteria Staphylococcus aureus, Bacillus sp., Bacillus cereus, Listeria ivanovii, Escherichia coli, Citrobacter freundii and Salmonella spp. The most significant activity was cytotoxicity against MCF-7 cells $(2 \mu \mathrm{M})$. This is the first report of such an accumulation of eburicol in the marine fungal strain C. rosea confirming its potential in the production of bioactive lipids.
\end{abstract}

Keywords: Clonostachys rosea; marine fungi; sterol; eburicol; cytotoxicity; antibacterial activity

\section{Introduction}

Lipids are actively involved in metabolic reactions like cell recognition, trans-membrane signaling, apoptosis, and growth or cell differentiation [1]. Among them, sterols are essential for the organization and functioning of eukaryotic organisms since they are components of cell membranes and they determine the permeability and fluidity of the membrane, therefore playing a crucial role in this dynamic [2-4]. The presence of sterols in every eukaryotic organism highlights the importance of these molecules in biological evolution [5,6]. Although sterols are present in all organisms, a great diversity can be observed depending on the kingdom studied. For example, within fungi, ergosterol is the main sterol which is present in the plasma membrane, unlike animals, in which it is cholesterol $[7,8]$. Biosynthetic pathways of those two sterols are distinct but have squalene as a common precursor. It is 
well known that sterols are studied for their importance for human nutrition [9]. Over the last few decades, numerous studies have described sterols, or more largely steroids, as bioactive compounds with antibacterial and anti-inflammatory activities or cytotoxicity against human cancer cells [10-17]. For example, a 24-branched $\Delta 5$ sterol isolated from a red seaweed was described as having antibacterial activity [18].

The exploration of microorganisms as sources of new bioactive compounds has a much more recent history in comparison to the use of plants or plant extracts in human medicine. However, the large number and variety of therapeutic agents isolated from microbial origins and used to treat human diseases have greatly contributed to the improvement of human health during the past century [19-21]. Among microorganisms, steroid compounds isolated from marine fungi have demonstrated bioactivities such as cytotoxicity against cancer cell lines [22,23]. For example, a new sterol, ergosta-8(14),22-diene-3,5,6,7-tetraol( $3 \beta, 5 \alpha, 6 \beta, 7 \alpha, 22 E)$, isolated from a marine Penicillium sp., exhibited cytotoxicity with $\mathrm{IC}_{50}$ values of $23 \mu \mathrm{M}$ against human liver cancer cell (Hep G) [11].

The present investigation was undertaken to study the sterol composition of 19 marine fungal strains and then to assess their biological activities. Antimicrobial tests were performed against four Gram-positive bacteria, namely Staphylococcus aureus, Bacillus sp., Bacillus cereus, Listeria ivanovii and three Gram-negative ones, Escherichia coli, Citrobacter freundii and Salmonella spp. For the cytotoxic activity, two breast and two lung cancer cell lines were chosen, namely MCF-7, MDA-MB-231, NSCLC-N6-L16 and A549.

\section{Results and Discussion}

\subsection{Marine Fungal Strains Screening}

To explore sterol chemodiversity on marine strains, a screening was performed on Dextrose Casein Agar (DCA) culture media with 19 marine fungal strains. They were selected from the fungal collection of the laboratory either because they are representative of the major genera (Trichoderma, Acremonium, Penicillium) of the Mer Molécules Santé (MMS) marine fungal strain collection or because an unusual biological active conjugated fatty acid was previously isolated from the strain (Clonostachys rosea MM1090) [24].

The total lipid (TL) content of all studied strains are reported in Table 1.

In Trichoderma strains, the TL content varied from 2.2\% (MMS1541) to 17.3\% (MMS852). The same variability for TL content was observed in strains belonging to Penicillium genus with values ranging from 2.7\% (MMS460) to 33.5\% (MMS646). Higher TL contents were measured in the case of Acremonium species in comparison to Trichoderma and Penicillium strains; they varied from $7.3 \%$ (MMS540) to 50.7\% (MMS889). Concerning C. rosea MMS1090, TL content was 21.4\%. These values are in agreement with previous studies on lipid production, even though lipid content can be improved by the optimization of cultures conditions (composition, carbon source, $\mathrm{pH}$ and temperature) [25-30].

After fungal biomass extraction, TL were saponified and sterols were identified by gaz chromatography coupled with mass spectrometry (GC-MS) based on a spectral data comparison with the literature (Table 1 and Scheme 1). The relative amounts were calculated using the percentage of peak area on chromatograms. Three major peaks were observed revealing a low complexity GC-MS profile of sterols produced by these strains. The main sterol observed in all unsaponifiable fractions was ergosterol (3e) $\left(\mathrm{m} / \mathrm{z} 396\left[\mathrm{M}^{+\bullet}\right)\right.$ with contents ranging from 26.5\% (MMS646) to 77.2\% (MMS13) which represents a high variability but is in agreement with the literature [7]. In most strains (16/19), the second most abundant sterol was ergostatetraenol (3f) (ergosta-5,7,22,24(28)-tetraen-3 $\beta$-ol, $\mathrm{m} / \mathrm{z} 394$ $[\mathrm{M}]^{+\bullet}$ ) with contents ranging from 2.2\% (Acremonium sp. MMS700) to $12.8 \%$ (Trichoderma sp. MMS1541). This compound is known to be a precursor of ergosterol [31]. The third most abundant compound was ergostapentaene (6e) (ergost-3,5,7,9(11),22-pentaene, $m / z 376\left[\mathrm{M}^{+\bullet}\right.$ ), with an amount ranging from $3.2 \%$ (Acremonium sp. MMS700) to $11.3 \%$ (Acremonium sp. MMS540). This compound was already observed in many studies of fungal sterols [17,32]. Neoergosterol (4e) (19-Norergosta-5,7,9,22-tetraen-3 $\beta$-ol), 
$m / z 380[\mathrm{M}]^{+\bullet}$ ) was also observed in all fungal strains, except $C$. rosea MMS1090 where it was not detected. Its content ranged from 2.4\% (Trichoderma sp. MMS13) to 4.9\% (Trichoderma sp. MMS1541). Neoergosterol was reported to be a metabolite of ergosterol [33,34]. A fifth sterol was also observed in 13 out of the 19 strains studied corresponding to a C31:2 sterol with $m / z 440[\mathrm{M}]^{+\bullet}$, most probably eburicol (1) $\mathbf{1 b}$. It was a very minor compound $(<1 \%)$ for three Penicillium strains (MMS42, MMS330 and MMS460), two Trichoderma (MMS639 and MMS755) and two Acremonium ones (MMS700 and MMS713); and detected in trace amount $(<0.5 \%)$ in the case of T. citrinoviride MMS19. Its maximum content was observed in the cases of $C$. rosea MMS1090 (9.4\%) where this content was unusual as it represented the second most abundant sterol of this strain. Eburicol content has been mostly studied in pathogenic strains when treated with antifungals [35]. To the best of our knowledge, only one study has investigated the cytotoxicity of eburicol against KB cells and multi-drug resistant strain KB-VIN cells, but no growth inhibition was observed at $20 \mu \mathrm{M}$ [14]. C. rosea MMS1090 was chosen to purify and thus assess the biological potential effects of eburicol.<smiles>[2H]C1CC[C@]2(C)C3=C(CC[C@]12C)[C@@]1(C)CC[C@H](O)[C@@H](O)CC[C@@]31C</smiles><smiles>C=C(CCC(C)C)C(=C)CCC(C)C</smiles><smiles>[2H]C1CCC2C3=CC=C4C[C@H](O)CC[C@]4(C)C3=CC[C@]12C</smiles><smiles>CC1CCC2C3=CC=C4C=CCC[C@]4(C)C3CCC12C</smiles><smiles>[2H]C1CC[C@]2(C)C3=C(CC[C@H]12)[C@@]1(C)CC[C@H](O)C(C)(C)C1CC[C@H]3O</smiles>
$5 \mathrm{e}$ $6 \mathrm{e}$<smiles>C=C(/C=C/C(C)C)C(C)C</smiles>

Scheme 1. Structure of the steroid compounds.

Table 1. Total lipid (TL) content and relative unsaponifiable composition of the different strains screened $(n=1)$.

\begin{tabular}{|c|c|c|c|c|c|c|c|}
\hline \multirow[b]{2}{*}{ Genus } & \multirow[b]{2}{*}{ Strain } & \multirow{2}{*}{$\begin{array}{l}\text { TL Content } \\
(\% \text { w/DW })\end{array}$} & \multicolumn{5}{|c|}{$\begin{array}{l}\text { Relative Unsaponifiable Composition (\% of Total Unsaponifiable Fraction) } \\
\text { as Free Compounds }\end{array}$} \\
\hline & & & $\begin{array}{c}\text { Ergostapentaene } \\
\text { (6e) } \\
m / z 376[\mathrm{M}]^{+\bullet}\end{array}$ & $\begin{array}{c}\text { Ergostatetraenol } \\
(3 \mathrm{f}) \\
m / z 394[\mathrm{M}]^{+\bullet}\end{array}$ & $\begin{array}{c}\begin{array}{c}\text { Ergosterol } \\
(3 \mathrm{e})\end{array} \\
m / z 396[\mathrm{M}]^{+\bullet}\end{array}$ & $\begin{array}{c}\text { Neoergosterol } \\
\text { (4e) } \\
m / z 380[\mathrm{M}]^{+\bullet}\end{array}$ & $\begin{array}{c}\text { Eburicol } \\
(1 \mathrm{~b}) \\
m / z 440[\mathrm{M}]^{+\bullet}\end{array}$ \\
\hline \multirow{7}{*}{ Trichoderma } & MMS13 & 13 & 4.8 & 4.5 & 77.2 & 2.4 & ND \\
\hline & MMS19 & 9 & 7.9 & 10.2 & 43.5 & 2.5 & $\operatorname{Tr}$ \\
\hline & MMS510 & 5.8 & 4.3 & 4.8 & 66.8 & 3.1 & ND \\
\hline & MMS639 & 12.9 & 5.1 & 5.5 & 63.8 & 3.5 & 0.7 \\
\hline & MMS755 & 8.8 & 5.1 & 10.7 & 50.8 & 3.9 & 0.8 \\
\hline & MMS852 & 17.3 & 6.5 & 3.1 & 79.2 & 4.3 & ND \\
\hline & MMS1541 & 2.2 & 6.0 & 12.8 & 22.8 & 4.9 & 1.5 \\
\hline
\end{tabular}


Table 1. Cont.

\begin{tabular}{|c|c|c|c|c|c|c|c|}
\hline \multirow[b]{2}{*}{ Genus } & \multirow[b]{2}{*}{ Strain } & \multirow{2}{*}{$\begin{array}{l}\text { TL Content } \\
(\% \text { w/DW })\end{array}$} & \multicolumn{5}{|c|}{$\begin{array}{l}\text { Relative Unsaponifiable Composition (\% of Total Unsaponifiable Fraction) } \\
\text { as Free Compounds }\end{array}$} \\
\hline & & & $\begin{array}{c}\text { Ergostapentaene } \\
(6 \mathbf{e}) \\
m / z 376[\mathrm{M}]^{+\bullet}\end{array}$ & $\begin{array}{c}\text { Ergostatetraenol } \\
(3 \mathrm{f}) \\
m / z 394[\mathrm{M}]^{+\bullet}\end{array}$ & $\begin{array}{c}\begin{array}{c}\text { Ergosterol } \\
(3 \mathrm{e})\end{array} \\
m / z 396[\mathrm{M}]^{+\bullet}\end{array}$ & $\begin{array}{c}\text { Neoergosterol } \\
\text { (4e) } \\
m / z 380[\mathrm{M}]^{+\bullet}\end{array}$ & $\begin{array}{c}\text { Eburicol } \\
\text { (1b) } \\
m / z 440[\mathrm{M}]^{+\bullet}\end{array}$ \\
\hline Mean & & $10 \pm 5$ & $6 \pm 1$ & $7 \pm 4$ & $54 \pm 20$ & $3.5 \pm 0.9$ & $0.5 \pm 0.4$ \\
\hline \multirow{7}{*}{ Acremonium } & MMS540 & 7.3 & 11.3 & 11.5 & 30.8 & 3.9 & ND \\
\hline & MMS594 & 18.1 & 5.4 & 9.3 & 44.7 & 3.5 & 2.1 \\
\hline & MMS700 & 11.4 & 3.2 & 2.2 & 65.5 & 3.8 & 0.6 \\
\hline & MMS713 & 9.2 & 3.3 & 6.5 & 66.3 & 3.5 & 0.5 \\
\hline & MMS862 & 8 & 5.1 & 8.8 & 59.9 & 4.1 & 2.4 \\
\hline & MMS887 & 20.1 & 7.4 & 8.9 & 56.1 & 3.2 & 5.4 \\
\hline & MMS889 & 50.7 & 5.0 & 7.3 & 73.3 & 4.1 & ND \\
\hline Mean & & $18 \pm 15$ & $6 \pm 3$ & $8 \pm 3$ & $57 \pm 15$ & $3.7 \pm 0.3$ & $2 \pm 2$ \\
\hline \multirow{4}{*}{ Penicillium } & MMS42 & 5.7 & 4.0 & 5.5 & 60.3 & 3.1 & 0.6 \\
\hline & MMS330 & 2.9 & 6.1 & 7.6 & 49.3 & 3.4 & 0.7 \\
\hline & MMS460 & 2.7 & 5.8 & 7.0 & 48.1 & 2.8 & 0.8 \\
\hline & MMS646 & 33.5 & 5.1 & 8.3 & 26.5 & 2.8 & ND \\
\hline Mean & & $11 \pm 15$ & $5.3 \pm 0.9$ & $7 \pm 1$ & $46 \pm 14$ & $3 \pm 0.3$ & $0.5 \pm 0.1$ \\
\hline Clonostachys & MMS1090 & 21.4 & 6.6 & 5.5 & 66.2 & ND & 9.4 \\
\hline
\end{tabular}

DW: dry weight; Tr: traces $<0.5 \%$; N.D.: Not Detected.

\subsection{OSMAC Approach: Eburicol Production}

To explore further eburicol production by C. rosea MMS1090 and optimize its culture conditions, a one strain many compounds (OSMAC) approach [36] was performed using seven culture media. The variation of the unsaponifiable content was assessed in the case of all culture media (Table 2). The results obtained indicated the ability of C. rosea MMS1090 to use the different available nutrients provided in the culture media leading to some differences in sterol production. A low variability of sterol content was observed (values from 7.5\%-Kohlmeyer solid (KMS) and potato dextrose agar (PDA)-to $12.5 \%$-yeast extract sucrose (YES)). Interestingly, as previously reported, the highest lipid production was obtained using the YES medium [24]. The high sterol content using YES medium could be explained by the high sucrose content of these particular culture medium $(150 \mathrm{~g} / \mathrm{L})$, which will engage the lipid cells accumulation. In fact, under suitable culture conditions, some microorganisms may convert the carbon sources from several substrates into storage lipid, from which neutral lipids may represent about $90 \%$ of total cumulated lipids [29,37,38]; neutral lipids being mainly triglycerides, free fatty acids and sterols. Cultures conditions such as $\mathrm{pH}$, temperature, carbon source and $\mathrm{C} / \mathrm{N}$ ratio may change lipid production and composition $[26,28,30,39,40]$. These neutral lipids have a real importance in fungal growth and their content depends on the physiological state of the fungal culture.

Ergosterol remains the most abundant sterol produced by C. rosea MMS1090 whatever the culture conditions. The highest ergosterol contents were obtained on PDA and malt extract agar (MEA) media, $80.9 \%$ and $72.4 \%$, respectively, and the lowest values were observed on KMS and YES culture media, $61.5 \%$ and $61.8 \%$, respectively. The highest eburicol content was observed in extracts from C. rosea MMS1090 on YES culture medium, 11.7\% of the total unsaponifiable. Lowest values were observed in extracts obtained from cultures on PDA and galactose casein agar (GCA) media, 2.3\% and $2.7 \%$, respectively. 
Table 2. Unsaponifiable content of total lipids (\% $w / w$ of TL) and relative composition of the unsaponifiable fraction (\% of unsaponifiable) from MMS 1090 based on the seven culture media $(n=3)$ as free compounds.

\begin{tabular}{|c|c|c|c|c|c|c|c|c|c|c|c|}
\hline \multirow[b]{2}{*}{ Culture Media } & \multirow{2}{*}{$\begin{array}{c}\text { Unsaponifiable } \\
\text { Content } \\
\text { (\% w/w of TL) }\end{array}$} & \multicolumn{10}{|c|}{ Relative Unsaponifiable Composition of MMS1090 Lipid Extract (\% of Unsaponifiable Fraction) as Free Compounds } \\
\hline & & $\begin{array}{c}\text { Ergostapentaene } \\
\text { (6e) }\end{array}$ & $\begin{array}{l}\text { 9-dehydroergosterol } \\
\text { (5e) }\end{array}$ & $\begin{array}{l}\text { Ergostatrienol } \\
\quad(3 b)\end{array}$ & $\begin{array}{c}\text { Ergosterol } \\
\text { (3e) }\end{array}$ & $\begin{array}{l}\text { Ergostadienol } \\
\quad(2 e)\end{array}$ & $\underset{\text { (4e) }}{\text { Neoergosterol }}$ & $\begin{array}{l}\text { Fungisterol } \\
\text { (2d) }\end{array}$ & $\begin{array}{l}\text { Lanosterol } \\
\text { (1a) }\end{array}$ & $\begin{array}{c}\text { Eburicol } \\
\text { (1b) }\end{array}$ & Others \\
\hline DCA & $8.8 \pm 1.4$ & $5.9 \pm 0.6$ & $5.0 \pm 0.5$ & $1.9 \pm 0.2$ & $63.2 \pm 3.3$ & $4.7 \pm 0.6$ & $2.2 \pm 0.2$ & $0.8 \pm 0.2$ & $\operatorname{Tr}{ }^{(1)}$ & $8.0 \pm 1.3$ & $8.2 \pm 1.1$ \\
\hline GCA & $9.5 \pm 1.1$ & $4.7 \pm 0.9$ & & $3.1 \pm 0.4$ & $68.2 \pm 6.3$ & $2.8 \pm 0.3$ & $2.5 \pm 0.4$ & $\operatorname{Tr}\left({ }^{(1)}\right.$ & $0.3 \pm 0.2$ & $2.7 \pm 0.8$ & $13.7 \pm 2$ \\
\hline CYA & $10.6 \pm 2.4$ & $5.1 \pm 1.2$ & $5.5 \pm 0.8$ & $1.4 \pm 0.5$ & $65.1 \pm 3.8$ & $8.9 \pm 1.3$ & $1.8 \pm 0.5$ & $1.7 \pm 0.1$ & $\mathrm{ND}^{(1)}$ & $5.6 \pm 0.5$ & $4.9 \pm 1.2$ \\
\hline KMS & $7.5 \pm 3.5$ & $4.7 \pm 0.9$ & $5.9 \pm 0.7$ & $2.8 \pm 0.1$ & $61.5 \pm 3.8$ & $3.6 \pm 0.8$ & $2.6 \pm 0.7$ & $1.3 \pm 1.1$ & $\operatorname{Tr}(1)$ & $3.81 \pm 0.06$ & $12.7 \pm 1.2$ \\
\hline PDA & $7.5 \pm 1.8$ & $3.3 \pm 0.5$ & $1.7 \pm 0.3$ & $0.9 \pm 0.1$ & $80.9 \pm 1.3$ & $5.4 \pm 0.5$ & $1.97 \pm 0.02$ & $0.6 \pm 0.3$ & $\mathrm{ND}^{(1)}$ & $2.3 \pm 0.6$ & $2.9 \pm 0.4$ \\
\hline MEA & $10.0 \pm 2.5$ & $3.4 \pm 0.3$ & $3.6 \pm 0.4$ & $1.3 \pm 0.2$ & $72.4 \pm 4.1$ & $2.9 \pm 0.4$ & $2.0 \pm 0.5$ & $0.8 \pm 0$ & $\operatorname{Tr}(1)$ & $7.5 \pm 0.8$ & $6.1 \pm 1.3$ \\
\hline
\end{tabular}

(1) Tr: traces $<0.5 \%$; ND: Not Detected. 
To get a more comprehensive view of the data, unsaponifiable compositions were analyzed by principal component analysis (PCA) (Figure 1). The first two axes already represent accurately the data variability as they explain $74 \%$ of total variance. Interestingly, based on the unsaponifiable composition, all extracts cluster according to culture medium. This emphasizes the link between culture medium composition and active biosynthetic pathway in C. rosea $[24,30]$. The exploration of the loadings responsible for such clustering indicates specific unsaponifiable composition for some medium: (1) YES medium extract contains a higher amount of eburicol and lanosterol (1a); (2) PDA medium extract contains a higher amount of ergosterol; (3) KMS and GCA medium extracts contain a higher level of ergosta-5,7,24(28)-trienol (3b); and (4) KMS and CYA (Czapek concentrate Agar) medium extracts contain a higher level of 9-dehydroergosterol (5e) and ergostapentaene. What is noteworthy is that eburicol accumulation in fungi is principally reported in pathogenic fungi treated with azole compounds. Indeed, eburicol is the principal substrate to CYP51, an enzyme which promotes $14 \alpha$-demethylation in sterols and which is inhibited by azole compounds. In this case, eburicol accumulation and ergosterol depletion therefore disrupt membrane organization and prevent further fungal growth [35,41-43].

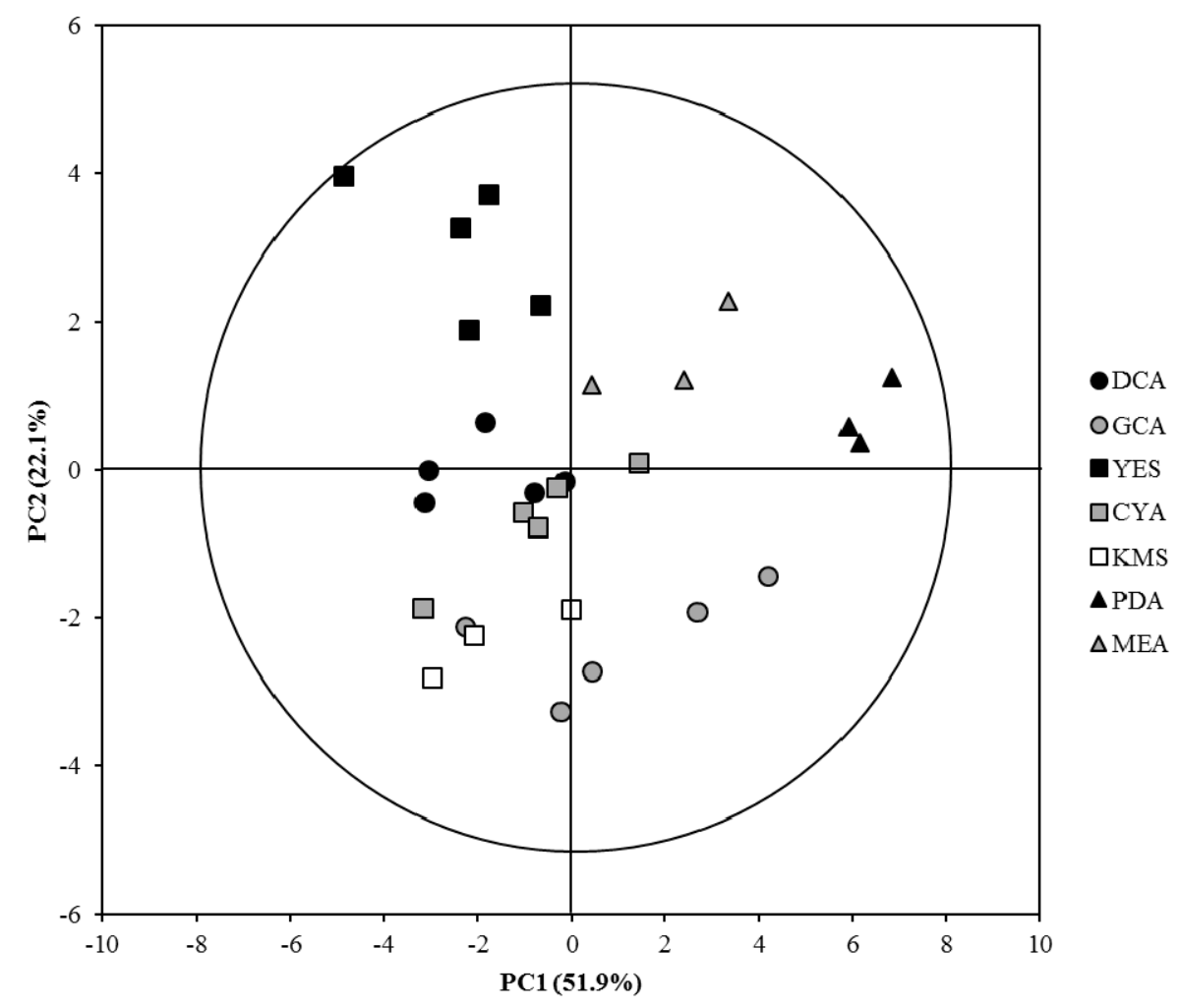

Figure 1. Principal component analysis (Pareto scaling) of unsaponifiable composition of C. rosea extracts according to culture medium.

\subsection{Structural Identification of Eburicol}

Two isomers are reported in the literature, eburicol and euphorbol (7c) and even by using GC-MS analyses, it is still not possible to identify which isomer is produced by C. rosea MMS1090. Therefore, a large-scale culture C. rosea MMS1090 was achieved using the YES culture medium to isolate and identify the observed isomer. After complete purification, the compound was observed as a white powder and the identification of the C31:2 sterol $(\mathrm{m} / \mathrm{z} 440)$ was achieved by analysis of spectral data (GC-MS, HR-ESI-MS, and ${ }^{1} \mathrm{H}$ and ${ }^{13} \mathrm{C} \mathrm{NMR}$ ), melting point (mp $\sim 155{ }^{\circ} \mathrm{C}$ ) and a literature comparison.

Initial identification was achieved using GC-MS spectrum (Figure 2). The ion at $m / z 425[\mathrm{M}-15]^{+\bullet}$, is characteristic for the presence of a $14 \alpha$-methyl group in a $\Delta 8$-sterol. The ion at $m / z 259$ [M - $15-$ 
side chain -42$]^{+\bullet}$ corresponded to a 24-methylene side chain and was in agreement with a $\mathrm{C}_{9} \mathrm{H}_{17}$ and a loss of the $14 \alpha$-methyl group [44].

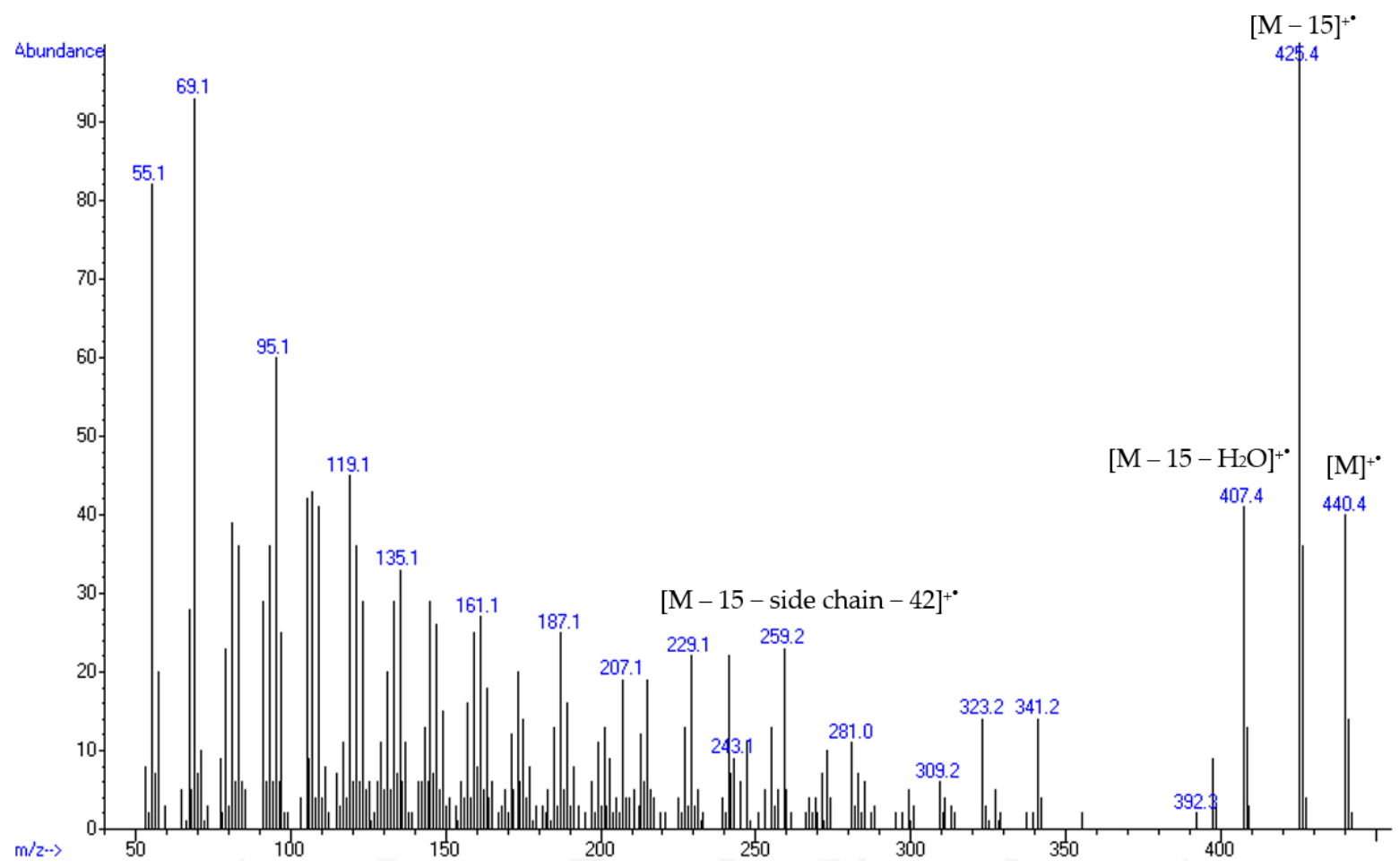

Figure 2. Gaz chromatography- mass spectrometry (GC-MS) spectrum of the C31:2 free sterol isolated from C. rosea MMS1090.

Concerning the NMR analyses (Table 3, Figures S1-S6, Supplementary information), the singlet methyl signal at 80.89 corresponded to methyl group $\left(31-\mathrm{CH}_{3}\right)$ branched in $\mathrm{C}-14$. A doublet signal at $\delta 4.67(J=1,2 \mathrm{~Hz})$ and the broad singlet at $\delta 4.72$ indicated the two C-28 protons, characteristic of a geminal coupling. Doublets were also observed at $\delta 0.93(J=6.4 \mathrm{~Hz}), \delta 1.04(J=6.9 \mathrm{~Hz})$ and $\delta 1.03$ $(J=6.9 \mathrm{~Hz})$ for the $\mathrm{C}-21, \mathrm{C}-26$ and $\mathrm{C}-27$ methyl groups. The ${ }^{1} \mathrm{H}$ NMR signals were diagnostic for sterols with a $14 \alpha$-methyl and 8(9)- and 24(28)-diene structure [45]. Analysis of the ${ }^{13} \mathrm{C}$ NMR spectral data for the C31:2 isolated sterol showed signals in agreement with those for a 24-methylenelanost-8-en-3 $\beta$-ol and were in agreement with shifts reported for eburicol in the literature (Scheme 2) [45-47].

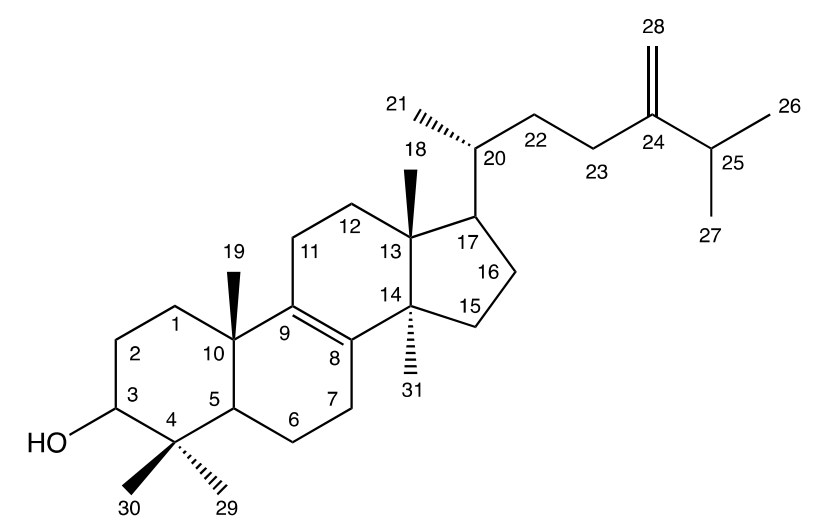

Scheme 2. Eburicol structure. 
Table 3. ${ }^{1} \mathrm{H}$ NMR (400.13 MHz) and ${ }^{13} \mathrm{C}$ NMR (100.61 MHz) in $\mathrm{CDCl}_{3}$ of eburicol.

\begin{tabular}{|c|c|c|c|}
\hline Position & ${ }^{1} \mathrm{H}$ NMR $\delta$ (ppm) & m, J (Hz) & ${ }^{13} \mathrm{C}$ NMR $\delta(\mathrm{ppm})$ \\
\hline 1 & $1.35-2.34$ & $M$ & 35.6 \\
\hline 2 & $1.35-2.34$ & $M$ & 27.8 \\
\hline 3 & 3.24 & $d d, 4.7$ and 11.5 & 79.0 \\
\hline 4 & - & - & 38.6 \\
\hline 5 & $1.35-2.34$ & $M$ & 50.4 \\
\hline 6 & $1.35-2.34$ & $M$ & 18.2 \\
\hline 7 & $1.35-2.34$ & $M$ & 28.2 \\
\hline 8 and 9 & - & - & 134.4 \\
\hline 10 & - & - & 37.0 \\
\hline 11 & $1.35-2.34$ & $M$ & 21.0 \\
\hline 12 & $1.35-2.34$ & $M$ & 26.5 \\
\hline 13 & - & - & 44.5 \\
\hline 14 & - & - & 49.8 \\
\hline 15 & $1.35-2.34$ & $M$ & 31.3 \\
\hline 16 & $1.35-2.34$ & $M$ & 31.0 \\
\hline 17 & $1.35-2.34$ & $M$ & 50.4 \\
\hline 18 & 0.70 & $S$ & 15.7 \\
\hline 19 & 0.99 & $S$ & 18.7 \\
\hline 20 & $1.35-2.34$ & $M$ & 36.5 \\
\hline 21 & 0.93 & $d, 6,4$ & 19.1 \\
\hline 22 & $1.35-2.34$ & $M$ & 35.0 \\
\hline 23 & $1.35-2.34$ & $M$ & 30.8 \\
\hline 24 & - & - & 156.9 \\
\hline 25 & 2.24 & $M$ & 22.0 \\
\hline 26 & 1.04 & $d, 6.9$ & 33.8 \\
\hline 27 & 1.03 & $d, 6.9$ & 21.9 \\
\hline 28 & 4.67 and 4.72 & $d$ and $s, 1.2$ & 105.9 \\
\hline 29 & 0.82 & $S$ & 15.4 \\
\hline 30 & 1.01 & $S$ & 27.9 \\
\hline 31 & 0.89 & $S$ & 24.3 \\
\hline $\mathrm{OH}$ & 5.35 & $m$ & \\
\hline
\end{tabular}

The molecular formula of eburicol, $\mathrm{C}_{31} \mathrm{H}_{53} \mathrm{O}$, was deduced by the ion detected at $\mathrm{m} / z 463.3908$ $[\mathrm{M}+\mathrm{Na}]^{+}$in HR-ESI-MS (calculated for $\mathrm{C}_{31} \mathrm{H}_{52} \mathrm{ONa}\left[\mathrm{M}+\mathrm{Na}^{+}:\right.$463.3910). The melting point (mp $\sim 155^{\circ} \mathrm{C}$ ) was in accordance with those reported in the literature for eburicol [45]; with the euphorbol isomer having an $\mathrm{mp}$ at around $123-126^{\circ} \mathrm{C}$ [48]. It is important to note that eburicol is the isomer generally found in fungi as it is a precursor of ergosterol [35] and euphorbol is mostly present in plants [49].

\subsection{Biological Activities of Eburicol}

\subsubsection{Antiproliferative Activity of Eburicol against Human Cancer Cells}

Until now, several studies have been carried out on the cytotoxicity of sterols, especially ergosterol and its derivatives $[17,22,50]$. Therefore, eburicol was tested against breast cancer cell lines (MCF-7 and MDA) and lung cancer cell lines (NSCLC-N6-L16 and A549) to assess their antiproliferative activity using MTT assays (Table 4).

Eburicol exhibited cytotoxic activities on the four human cancer cell lines with $\mathrm{IC}_{50}$ lower than $40 \mu \mathrm{M}$. The most important activity was observed against the largely studied breast cancer cell line MCF-7 with $\mathrm{IC}_{50}$ at $2 \mu \mathrm{M}$ which is the lowest for a sterol compound compared to literature. It should be noted that obtusifoliol (8b), although having a structure closely related to eburicol (a 4-methyl group instead of a 4,4-dimethyl group), exhibited a lower cytotoxic activity against MCF-7 and MDA-MB-231 cell lines [51]. 
Table 4. Cytotoxic activities of eburicol compared to literature.

\begin{tabular}{lccccc}
\hline \multirow{2}{*}{$\begin{array}{c}\text { Sterol } \\
\text { Compounds }\end{array}$} & \multicolumn{4}{c}{ IC $_{\mathbf{5 0}}(\boldsymbol{\mu M})$} & \multirow{2}{*}{ Reference } \\
\cline { 2 - 5 } & MCF-7 & MDA-MB-231 & NSCLC-N6-L16 & A549 & \\
\hline Eburicol & $\mathbf{2 . 0 \pm 0 . 7}$ & $15.7 \pm 0.9$ & $24.5 \pm 0.5$ & $38 \pm 3$ & Present study \\
Obtusifoliol & 29.3 & 41.8 & - & - & {$[51]$} \\
Gorgosterol & 71.2 & - & - & - & {$[52]$} \\
4-methyl sterol & - & - & - & $\mathbf{4 . 9}$ to $>100$ & {$[53]$} \\
Ketone sterols & - & - & - & 40.4 & {$[22]$} \\
Hydroperoxysterol & 20.5 & - & - & - & {$[54]$} \\
Polyhydroxysterols & $10.6-71.9$ & - & & & {$[52]$} \\
\hline
\end{tabular}

On the other hand, among 10 ketone sterols isolated from a marine-derived fungi Rhizopus sp., the cytotoxic activity on another largely studied lung cancer cell line A549 was stronger ( IC $\left._{50} 4.9 \mu \mathrm{M}\right)$ for $3 \beta, 15 \alpha$-dihydroxyl-(22E,24R)-ergosta-5,8(14),22-trien-7-one [22]. This compound also demonstrated activity against two other cancer cell lines (P388: $\mathrm{IC}_{50} 1.4 \mu \mathrm{M}$ and HL-60: $\mathrm{IC}_{50} 0.3 \mu \mathrm{M}$ ). More recently, new highly oxygenated sterols isolated from Cladosporium sp., a marine sponge-derived fungus, were inactive against the three selected tumor cell lines used in the study (MCF-7, K562, and SGC-7901) [55].

\subsubsection{Antimicrobial Activity of Eburicol against Human Pathogenic Bacteria}

Bacterial infections remain a significant threat to human health. Due to the emergence of widespread antibiotic resistance, development of novel antibiotics is required in order to ensure that effective treatment remains available. Therefore, the antimicrobial activity of eburicol was also assessed against human pathogenic bacteria B. cereus, Bacillus sp., L. ivanovii, S. aureus (Gram-positive bacteria) and C. freundii, E. coli, Salmonella spp. (Gram-negative bacteria). A preliminary study was realized using the inhibition diameter (Table S1). Generally, a weak antimicrobial activity was observed against all bacteria with the highest inhibition zone $(24 \mathrm{~mm})$ for eburicol observed at $100 \mu \mathrm{g} / \mathrm{mL}$ on S. aureus. The minimum inhibitory concentration (MIC) was only determined against this strain and the value obtained was $62.5 \mu \mathrm{g} / \mathrm{mL}(142 \mu \mathrm{M})$.

To compare with other natural steroid compounds, ergosterol, the major sterol in lots of fungi, exhibited an MIC $>252 \mu \mathrm{M}$ against a methicilin-resistant $S$. aureus (MRSA) [16]. Moreover, lanostane triterpenes isolated from Fomitopsis rosea demonstrated only weak antibacterial activity against a S. aureus strain, at $400 \mu \mathrm{g} / \mathrm{mL}$ with an inhibition zone from 14 to $25 \mathrm{~mm}$ [56]. Moreover, phytosterols, for example, sitosterol, campesterol and stigmasterol, with a $\Delta 5$ unsaturation, are known to present antibacterial activity against S. aureus, S. albus, Streptococcus viridans, E. coli, Pseudomonas pyocyanea, and Klebsiella [57]. Among $\Delta 5$ sterols, the most active one is the 24-propylidenecholest-5-en-3 $\beta$-ol isolated from Laurencia papillosa red seaweed which shows an antibacterial activity against $S$. aureus ATCC25923 (MIC $=0.53$ $\mu \mathrm{g} / \mathrm{mL}$ ) [18]. Only two publications reported antibacterial activity of $\Delta 7$ steroids against $S$. aureus ATCC 6538 with ergosta-7,22-dien-3-one and ergosta-7,22-dien-3 $\beta$-ol, which did not demonstrate any activity [58] while 24 -methyl- $5 \alpha$-cholesta-7,22-dien-3 $\beta$-ol and 24 -methyl- $5 \alpha$-cholest-7-en-3 $\beta$-ol exhibited a light one, with a MIC of $2 \mathrm{mg} / \mathrm{mL}$ on S. aureus ATCC 25923 strain sensitive to penicillin and tetracycline [59]. In the best of our knowledge, any activity has been reported before for a 4,4-dimethyl sterol or a $\Delta 8$ sterol.

\section{Materials and Methods}

\subsection{Marine Fungal Strains}

Fungal strains were isolated from shellfish farming areas of the French Atlantic west coast. Fungal identifications were performed on the basis of their morphological and microscopic features and were completed for 11 strains by sequencing the internal transcribed spacers ITS1 and ITS2 and the $5.8 \mathrm{~S}$ regions and deposited in GenBank. The strains were conserved in the fungal collection 
of the MMS laboratory of the University of Nantes under the reference MMS + number. Nineteen strains from four genera were selected: Trichoderma harzanium MMS13 (access number: JQ653065); T. citrinoviride MMS19 (JQ608473); T. reesei MMS510 (GU947793); T. atroviride MMS639 (JQ653056); T. capilare MMS755 (JQ653068); T. capilare MMS852 (JQ653070); T. pleuroticola MMS1541 (JQ653064); Acremonium sp. MMS540; Acremonium sp. MMS594; Acremonium sp. MMS700; Acremonium sp. MMS713; Acremonium sp. MMS862; Acremonium sp. MMS887; Acremonium sp. MMS889; Penicillium expansum MMS42 (JN794527); P. ubiquetum MMS330 (MH172366); P. canescens MMS460 (KU720405); Penicillium sp. MMS646; Clonostachys rosea MMS1090 (KR011118).

\subsection{Culture Media Conditions}

Petri dishes (10 cm diameter) were inoculated with conidia suspension $\left(1 \times 10^{6}\right.$ cells $\left./ \mathrm{mL}\right)$ on seven marine-like solid media prepared with artificial seawater (Reef Crystals $36 \mathrm{~g} / \mathrm{L}$ ): DCA (Dextrose $40 \mathrm{~g} / \mathrm{L}$, enzymatic digest of casein $10 \mathrm{~g} / \mathrm{L}$, agar $15 \mathrm{~g} / \mathrm{L}$, Difco); CYA (Czapek concentrate $10 \mathrm{~mL}$, yeast extract $5 \mathrm{~g} / \mathrm{L}, \mathrm{K}_{2} \mathrm{HPO}_{4} 1 \mathrm{~g} / \mathrm{L}$, trace metal solution $1 \mathrm{~mL}$, sucrose $30 \mathrm{~g} / \mathrm{L}$, Agar $15 \mathrm{~g} / \mathrm{L}$ ); YES (yeast extract $20 \mathrm{~g} / \mathrm{L}$, sucrose $150 \mathrm{~g} / \mathrm{L}$, agar $20 \mathrm{~g} / \mathrm{L}$ plus salts); GCA (galactose $40 \mathrm{~g} / \mathrm{L}$, enzymatic digest of casein $10 \mathrm{~g} / \mathrm{L}$, agar $15 \mathrm{~g} / \mathrm{L}$ ); KMS (Kohlmeyer solid, dextrose $5 \mathrm{~g} / \mathrm{L}, \mathrm{MgSO} 4,7 \mathrm{H}_{2} \mathrm{O} 2.4 \mathrm{~g} / \mathrm{L}, \mathrm{NH}_{4} \mathrm{NO}_{3} 2.4 \mathrm{~g} / \mathrm{L}$ Tris buffer $1.21 \mathrm{~g} / \mathrm{L}$, agar $15 \mathrm{~d} / \mathrm{L}$ ); PDA (potato extract $4 \mathrm{~g} / \mathrm{L}$, dextrose $20 \mathrm{~g} / \mathrm{L}, \mathrm{ZnSO}_{4}, 7 \mathrm{H}_{2} \mathrm{O} 0.01 \mathrm{~g} / \mathrm{L}, \mathrm{CuSO}_{4}, 5 \mathrm{H}_{2} \mathrm{O}$ $0.005 \mathrm{~g} / \mathrm{L}$, Agar $15 \mathrm{~g} / \mathrm{L}$ ); MEA (malt extract $20 \mathrm{~g} / \mathrm{L}$, peptone $1 \mathrm{~g} / \mathrm{L}$, dextrose 20g/L, Agar $20 \mathrm{~g} / \mathrm{L}$ ). Cultures were incubated in natural light for 10 days at $27^{\circ} \mathrm{C}$.

\subsection{Lipid Extraction and Saponification}

For each culture media, the biomass on Petri dishes was scrapped off and removed using a scalpel and allowed to dry in an oven at $65^{\circ} \mathrm{C}$ and weighed. Lipids were extracted from the dried biomass by two-step $\mathrm{CH}_{2} \mathrm{Cl}_{2} / \mathrm{MeOH}$ extraction 2:1 then 1:2 (v/v) during $2 \mathrm{~h}$ at room temperature. The resulting extracts were filtered, pooled and washed with water $(0.08 \% \mathrm{KCl}, 40 \%$ of total volume). Then the organic phase was evaporated to dryness under vacuum providing total lipid crude extracts (TL) which was expressed as a percentage of the total extracted dry biomass. Total lipids were then saponified with ethanolic $\mathrm{KOH}(2 \mathrm{M})$ at $80{ }^{\circ} \mathrm{C}$ under reflux for $1.5 \mathrm{~h}$. After cooling, water and hexane were added, 1:2 (v/v), and the organic phase, containing sterols (unsaponifiable), was dried with anhydrous $\mathrm{Na}_{2} \mathrm{SO}_{4}$, filtered and the solvent was evaporated. The unsaponifiable fraction was analyzed by gas chromatography coupled with mass spectrometry (GC-MS, Hewlett Packard, Wilmington, DE, USA). A part of the unsaponifiable fraction was acetylated using acetic anhydride and pyridine and heated $1 \mathrm{~h}$ at $80^{\circ} \mathrm{C}$ in order to obtain sterol acetates.

\subsection{General Spectrometry Analysis}

Free and acetylated sterols were analyzed using a GC-MS instrument (Hewlett Packard HP 6890-GC System, Wilmington, DE, USA) linked to a mass detector (HP 6890-E.I. 70 eV) equipped with a SLB-5 ${ }^{\mathrm{TM}}$ column $(60 \mathrm{~m} \times 0.25 \mathrm{~mm} \times 0.25 \mu \mathrm{m})$. The carrier gas was helium at a flow rate of $1 \mathrm{~mL} / \mathrm{min}$. The temperatures of the injector and detector were respectively set at $250{ }^{\circ} \mathrm{C}$ and $280{ }^{\circ} \mathrm{C}$. One microliter was injected in splitless mode. The initial temperature of the GC-oven was $200^{\circ} \mathrm{C}$ with a subsequent increase $\left(3^{\circ} \mathrm{C} / \mathrm{min}\right)$ up to $310^{\circ} \mathrm{C}$. The solvent delay was $9 \mathrm{~min}$. The relative amount of each component was determined as the percent of the total ion current (TIC) as free compounds. Acetylated sterols were only used to identify the different molecules.

High resolution mass spectra were recorded using a Micromass Zab Spec Tof spectrometer (Waters Corporation, Milford, MA, USA) (positive mode, ion-source acceleration $4.5 \mathrm{kV}$, ion-source temperature $200{ }^{\circ} \mathrm{C}$, methanol as solvent). ${ }^{1} \mathrm{H}$ - and ${ }^{13} \mathrm{C}-\mathrm{NMR}$ spectra were obtained on a NMR Bruker Avance III 400 spectrometer (Ettlingen, Germany) with triple Probe TBI multinuclear in $\mathrm{CDCl}_{3}$ with tetramethylsilane as reference to an internal standard. Chemical shifts and coupling constants were expressed in $\delta(\mathrm{ppm})$ and $\mathrm{Hz}$, respectively. 


\subsection{Production, Purification and Structural Elucidation of Sterol from C. rosea MMS 1090}

For production of sterols, cultures of $C$. rosea MMS 1090 were performed on YES culture medium. Petri dishes $\left(20 \mathrm{~cm}\right.$ diameter, $125 \mathrm{~mL}$ ) were incubated at $27^{\circ} \mathrm{C}$ in natural light for 10 days. After biomass extraction, TL were separated as described previously [24]. Briefly, TL were separated in lipid classes on an open silica gel column (Kieselgel—60 $\AA-0.063-0.2 \mathrm{~mm}-\mathrm{ASTM}$ ). The crude extract from MMS1090 was separated in 20 fractions according to the eluents: D1 to D8 for dichloromethane fractions; A1 to A5 for acetone fractions; M1 to M7 for methanol fractions.

Lipid fractions composition was controlled by thin layer chromatography (TLC) performed on precoated silica gel $\mathrm{F}_{254}$ plates. After development, the dried plates were sprayed with $50 \%$ $\mathrm{H}_{2} \mathrm{SO}_{4}$-vanillin and orcinol reagents. Sterols were eluted from D3 to D8. The D3 fraction enriched in sterols was then purified by preparative TLC (hexane/diethyl ether/acetic acid: 50/50/0.75: v/v/v) in silica gel $\mathrm{F}_{254}$ plates. White amorphous powder (melting point $\sim 155^{\circ} \mathrm{C}$ ) was obtained. Fraction purity was monitored by GC-MS analysis.

\subsection{Cell Viability Assay}

Human breast cancer MCF-7 and MDA-MB-231 cells were purchased from the European Collection of Animal Cell Cultures (ECACC, Salisbury, UK). Human lung cancer NSCLC-N6-L16 and A549 (reference CCL-185) cell lines were obtained from IICiMED laboratory (Nantes, France) and the American Type Culture Collection (ATCC). Cells were cultured at $37^{\circ} \mathrm{C}$ in a humidified incubator with $5 \% \mathrm{CO}_{2}$. MCF-7 cells were cultured in DMEM medium supplemented with $10 \%$ fetal bovine serum (FBS), 1\% glutamine and 1\% penicillin-streptomycin. NSCLC-N6-L16 and A549 cells were cultured in RPMI 1640 medium with 5\% fetal calf serum, $100 \mathrm{IU}$ penicillin $/ \mathrm{mL}, 100 \mu \mathrm{g}$ streptomycin $/ \mathrm{mL}$ and $2 \mathrm{mM}$ glutamine.

The four cancer cell lines were treated with different concentrations of the purified sterol for $72 \mathrm{~h}$ and cell growth was estimated by a colorimetric assay based on the reduction of tetrazolium dye (MTT, Sigma Aldrich, Saint Quentin Fallavier, France) to a blue formazan product by live mitochondria. Optical density corresponding to solubilized formazan was read at $570 \mathrm{~nm}$. The relative cell viability was expressed as a percentage of the control that was not treated with sterol. Docetaxel was used as positive control for MCF-7 $\left(\mathrm{IC}_{50}=2.7 \mathrm{nM}\right)$ and for MDA-MB-231 $\left(\mathrm{IC}_{50}=100 \mathrm{nM}\right)$ and vinorelbine for $\mathrm{A} 549\left(\mathrm{IC}_{50}=0.13 \mu \mathrm{M}\right)$ and NSCLC-N6-L16 $\left(\mathrm{IC}_{50}=2.7 \mu \mathrm{M}\right)$.

\subsection{Antibacterial Activity against Human Pathogens}

The strains used to evaluate the antimicrobial activity were obtained from the collection of the Pasteur Institut (CIP) and the ATCC. Gram-positive bacteria were Staphylococcus aureus (ATCC 25923), Bacillus sp. (CIP 104717), Bacillus cereus (ATCC 33019), and Listeria ivanovii (ATCC 19119). Gram-negative bacteria were Escherichia coli (ATCC 10536), Citrobacter freundii (ATCC 8090) and Salmonella spp. Antibacterial activity of purified sterol was assessed in triplicates using agar diffusion with cellulose disks of $6 \mathrm{~mm}$ in diameter, dissolved in a minimum volume of solvent (dichloromethane) and cellulose disks were imbibed with different concentrations. After solvent evaporation, the disks were placed on the surface of a Petri dish previously seeded with $5 \mathrm{~mL}$ of a bacteria suspension $\left(0.2 \times 10^{4}\right.$ bacteria/mL) and incubated at $37^{\circ} \mathrm{C}$ for $24 \mathrm{~h}$. Two concentrations were tested (50 and $100 \mu \mathrm{g} / \mathrm{mL}$ ). Disks with the streptomycin standard at the same concentrations were used as control. The results were obtained by measuring the diameter of inhibition zone for each disk and expressed in millimeter. The determination of the minimum inhibitory concentration (MIC) was carried out according to the microtitre technique described by Sarker et al. [60] with some modifications. Briefly, $100 \mu \mathrm{L}$ of the eburicol were added and serial dilutions were performed to achieve final concentrations ranged from $0.24 \mu \mathrm{g} / \mathrm{mL}$ to $500 \mu \mathrm{g} / \mathrm{mL}$. Then $100 \mu \mathrm{L}$ of Mueller Hinton broth (BMH) inoculated with $100 \mu \mathrm{L}$ of a S. aureus suspension are added to reach a concentration of $10^{6} \mathrm{CFU} / \mathrm{mL}$. The antibacterial activity was examined after incubation at $37^{\circ} \mathrm{C}$ for $18-24 \mathrm{~h}$ using resazurin (7-hydroxy-3H-phenoxazin-3-one) as 
colored indicator. $\mathrm{BMH}$ without bacterial suspension was used as negative control and streptomycin as positive one $(\mathrm{MIC}=3.4 \mu \mathrm{M})$. All experiments were performed in triplicate.

\subsection{Statistical analyses}

Statistical analyses (principal component analyses) were performed using SIMCA-P $13^{\circledR}$ (Umetrics, Umeå, Sweden).

\section{Conclusions}

This present study compared sterol production between 19 marine-sourced fugal strains. For 17 strains, the major steroid compounds were by order of abundance ergosterol, ergostatetraenol, ergostapentaene, neoergosterol and eburicol. However, an unusual sterol production profile was observed in the case of $C$. rosea MMS1090 where the second most abundant sterol was eburicol, after ergosterol. To optimize culture conditions and produce high amounts of eburicol an OSMAC approach was performed. The highest lipid and eburicol production was obtained on YES culture conditions. After its isolation and structural identification, eburicol biological activities were evaluated. The present results showed that eburicol had a weak antimicrobial activity, against $S$. aureus (but proved a significant cytotoxic effect against two breast human cancer cell lines, in particular against MCF-7 at $2 \mu \mathrm{M}\left(\mathrm{IC}_{50}\right)$. To conclude, this study of fungal sterols confirmed the unusual profile of the marine-sourced Clonostachys rosea MMS1090 strains and confirms its potential in the production of bioactive lipids.

Supplementary Materials: The following are available online at http://www.mdpi.com/1660-3397/17/6/372/s1, Figure S1: ${ }^{1} \mathrm{H}$ NMR spectrum of Eburicol in $\mathrm{CDCl}_{3}\left(400 \mathrm{MHz}, 25^{\circ} \mathrm{C}\right)$; Figure S2. COSY spectrum of Eburicol in $\mathrm{CDCl}_{3}\left(400 \mathrm{MHz}, 25^{\circ} \mathrm{C}\right)$; Figure S3. Expanded HSQC spectrum of eburicol in $\mathrm{CDCl}_{3}\left(400 \mathrm{MHz}\right.$ for $\left.{ }^{1} \mathrm{H}, 25^{\circ} \mathrm{C}\right)$; Figure S4. Expanded HSQC spectrum of eburicol in $\mathrm{CDCl}_{3}\left(400 \mathrm{MHz}\right.$ for $\left.{ }^{1} \mathrm{H}, 25^{\circ} \mathrm{C}\right)$; Figure S5. Expanded $\mathrm{HMBC}$ spectrum of eburicol in $\mathrm{CDCl}_{3}\left(400 \mathrm{MHz}\right.$ for $\left.{ }^{1} \mathrm{H}, 25^{\circ} \mathrm{C}\right)$; Figure S6. Expanded $\mathrm{HMBC}$ spectrum of eburicol in $\mathrm{CDCl}_{3}\left(400 \mathrm{MHz}\right.$ for $\left.{ }^{1} \mathrm{H}, 25^{\circ} \mathrm{C}\right)$; Table S1. Evaluation of antimicrobial activity of eburicol against human pathogenic bacteria $(n=3)$. Values should be compared to the standard Streptomycin results $(12 \pm 2$ at $50 \mu \mathrm{g} / \mathrm{mL}$ and $15 \pm 2$ at $100 \mu \mathrm{g} / \mathrm{mL}$ for all strains).

Author Contributions: A.C.D.S.D. as PhD student was implied at all experimental stages. A.C.-M., N.R. and S.B. participated in data analyses, results exploitation and revised the article critically for intellectual content. S.E. supervised the biological part for antimicrobial activity and F.L. realized the experiments. C.R. and E.-H.N. supervised the biological part of this study, respectively on, NSCLC-N6-L16 and A549 cell lines and MCF-7 and MDA-MB-231 cell lines and L.O. realized the experiments. Y.F.P. supervised the choice of the strain and the fungal collection. G.W.-C. has been supervisor of the thesis work of A.C.D.S.D. and was responsible for writing arranging and checking the manuscript. All authors read and approved the final manuscript.

Funding: This research was funded by the CAPES Foundation, Ministry of Education of Brazil, Brasília-DF 70040-020, Brazil for the Ph.D. fellowship.

Acknowledgments: The authors acknowledge the technical platform CRMPO from University of Rennes 1 to NMR and HR-ESI-MS analyses. Thanks are also due to Flavie Moirand and Mendrika Raheriarivelo, for their help as trainees and Vony Rabesaotra, Christophe Tomasoni and Thibaut Robiou du Pont for their technical participation. The authors thank Lucas Bryk for English revisions of the manuscript.

Conflicts of Interest: The authors declare no conflict of interest.

\section{References}

1. Huang, C.; Freter, C. Lipid metabolism, apoptosis and cancer therapy. Int. J. Mol. Sci. 2015, 16, 924-949. [CrossRef] [PubMed]

2. Lipowsky, R.; Sackmann, E. Structure and Dynamics of Membranes: I. From Cells to Vesicles/II. Generic and Specific Interactions; Handbook of Biological Physics; Elsevier Science: Amsterdam, The Netherlands, 1995; ISBN 978-0-08-054191-4.

3. Maxfield, F.R.; Tabas, I. Role of cholesterol and lipid organization in disease. Nature 2005, 438, 612. [CrossRef] [PubMed] 
4. Czub, J.; Baginski, M. Comparative molecular dynamics study of lipid membranes containing cholesterol and ergosterol. Biophys. J. 2006, 90, 2368-2382. [CrossRef] [PubMed]

5. Burden, R.S.; Cooke, D.T.; Carter, G.A. Inhibitors of sterol biosynthesis and growth in plants and fungi. Phytochemistry 1989, 28, 1791-1804. [CrossRef]

6. Kerr, R.G.; Kerr, S.L.; Pettit, G.R.; Herald, D.L.; Groy, T.L.; Djerassi, C. Sterols of marine invertebrates. 63. Isolation and structure elucidation of sutinasterol, the major sterol of the marine sponge Xestospongia sp. J. Org. Chem. 1991, 56, 58-62. [CrossRef]

7. Nes, W.D.; Xu, S.; Haddon, W.F. Evidence for similarities and differences in the biosynthesis of fungal sterols. Steroids 1989, 53, 533-558. [CrossRef]

8. Risley, J.M. Cholesterol biosynthesis: Lanosterol to cholesterol. J. Chem. Educ. 2002, 79, 377. [CrossRef]

9. Piironen, V.; Lindsay, D.G.; Miettinen, T.A.; Toivo, J.; Lampi, A.-M. Plant sterols: Biosynthesis, biological function and their importance to human nutrition. J. Sci. Food Agric. 2000, 80, 939-966. [CrossRef]

10. Mizuno, T.; Saito, H.; Nishitoba, T.; Kawagishi, H. Antitumor-active substances from mushrooms. Food Rev. Int. 1995, 11, 23-61. [CrossRef]

11. Sun, Y.; Tian, L.; Huang, J.; Li, W.; Pei, Y. Cytotoxic sterols from marine-derived fungus Penicillium sp. Nat. Prod. Res. 2006, 20, 381-384. [CrossRef]

12. Chen, J.J.; Lin, W.J.; Liao, C.H.; Shieh, P.C. Anti-inflammatory benzenoids from Antrodia camphorata. J. Nat. Prod. 2007, 70, 989-992. [CrossRef] [PubMed]

13. Liu, X.T.; Winkler, A.L.; Schwan, W.R.; Volk, T.J.; Rott, M.; Monte, A. Antibacterial compounds from mushrooms II: Lanostane triterpenoids and an ergostane steroid with activity against Bacillus cereus isolated from Fomitopsis pinicola. Planta Med. 2010, 76, 464-466. [CrossRef] [PubMed]

14. Wu, S.J.; Leu, Y.L.; Chen, C.H.; Chao, C.H.; Shen, D.Y.; Chan, H.-H.; Lee, E.-J.; Wu, T.-S.; Wang, Y.-H.; Shen, Y.-C.; et al. Camphoratins A-J, potent cytotoxic and anti-inflammatory triterpenoids from the fruiting body of Taiwanofungus camphoratus. J. Nat. Prod. 2010, 73, 1756-1762. [CrossRef] [PubMed]

15. Shi, L.S.; Chao, C.H.; Shen, D.Y.; Chan, H.H.; Chen, C.H.; Liao, Y.-R.; Wu, S.-J.; Leu, Y.-L.; Shen, Y.-C.; Kuo, Y.-H.; et al. Biologically active constituents from the fruiting body of Taiwanofungus camphoratus. Bioorg. Med. Chem. 2011, 19, 677-683. [CrossRef] [PubMed]

16. Zhai, M.M.; Qi, F.M.; Li, J.; Jiang, C.X.; Hou, Y.; Shi, Y.P.; Di, D.L.; Zhang, J.W.; Wu, Q.X. Isolation of secondary metabolites from the soil-derived fungus Clonostachys rosea YRS-06, a biological control agent, and evaluation of antibacterial activity. J. Agric. Food Chem. 2016, 64, 2298-2306. [CrossRef]

17. Torres, S.; Cajas, D.; Palfner, G.; Astuya, A.; Aballay, A.; Pérez, C.; Hernández, V.; Becerra, J. Steroidal composition and cytotoxic activity from fruiting body of Cortinarius xiphidipus. Nat. Prod. Res. 2017, 31, 473-476. [CrossRef] [PubMed]

18. Kavita, K.; Singh, V.K.; Jha, B. 24-branched $\Delta 5$ sterols from Laurencia papillosa red seaweed with antibacterial activity against human pathogenic bacteria. Med. Extr. Microbiol. 2014, 169, 301-306. [CrossRef]

19. Demain, A.L.; Sanchez, S. Microbial drug discovery: 80 years of progress. J. Antibiot. (Tokyo) 2009, 62, 5-16. [CrossRef]

20. Genilloud, O. The re-emerging role of microbial natural products in antibiotic discovery. Antonie Van Leeuwenhoek 2014, 106, 173-188. [CrossRef]

21. Imhoff, F.J. Natural products from marine fungi-Still an underrepresented resource. Mar. Drugs 2016, 14, 19. [CrossRef]

22. Wang, F.; Fang, Y.; Zhang, M.; Lin, A.; Zhu, T.; Gu, Q.; Zhu, W. Six new ergosterols from the marine-derived fungus Rhizopus sp. Steroids 2008, 73, 19-26. [CrossRef] [PubMed]

23. Sun, L.; Li, D.L.; Tao, M.H.; Dan, F.J.; Zhang, W.M. Two new sesquiterpenes from the marine fungus Eutypella scoparia FS26 from the South China Sea. Helv. Chim. Acta 2012, 95, 157-162. [CrossRef]

24. Dias, C.A.; Ruiz, N.; Couzinet-Mossion, A.; Bertrand, S.; Duflos, M.; Pouchus, Y.F.; Barnathan, G.; Nazih, H.; Wielgosz-Collin, G. The marine-derived fungus Clonostachys rosea, source of a rare conjugated 4-Me-6E,8E-hexadecadienoic acid reducing viability of MCF-7 breast cancer cells and gene expression of lipogenic enzymes. Mar. Drugs 2015, 13, 4934-4938. [CrossRef] [PubMed]

25. Abraham, M.J.; Srinivasan, R.A. Lipid and fatty acid composition of selected fungi grown on whey medium. J. Food Sci. 1984, 49, 950-951. [CrossRef]

26. Brown, D.E.; Hasan, M.; Lepe-Casillas, M.; Thornton, A.J. Effect of temperature and pH on lipid accumulation by Trichoderma reesei. Appl. Microbiol. Biotechnol. 1990, 34, 335-339. [CrossRef] 
27. Suutari, M. Effect of growth temperature on lipid fatty acids of four fungi (Aspergillus niger, Neurospora crassa, Penicillium chrysogenum, and Trichoderma reesei). Arch. Microbiol. 1995, 164, 212-216. [CrossRef]

28. Ruiz, N.; Dubois, N.; Wielgosz-Collin, G.; Robiou du Pont, T.; Bergé, J.P.; Pouchus, Y.F.; Barnathan, G. Lipid content and fatty acid composition of a marine-derived Trichoderma longibrachiatum strain cultured by agar surface and submerged fermentations. Process Biochem. 2007, 42, 676-680. [CrossRef]

29. Chatzifragkou, A.; Fakas, S.; Galiotou-Panayotou, M.; Komaitis, M.; Aggelis, G.; Papanikolaou, S. Commercial sugars as substrates for lipid accumulation in Cunninghamella echinulata and Mortierella isabellina fungi. Eur. J. Lipid Sci. Technol. 2010, 112, 1048-1057. [CrossRef]

30. Dias, C.A.; Couzinet-Mossion, A.; Ruiz, N.; Le Bellec, M.; Gentil, E.; Wielgosz-Collin, G.; Bertrand, S. Sugar induced modification in glycolipid production in Acremonium sp. revealed by LC-MS lipidomic approach. Curr. Biotechnol. 2017, 6, 227-237.

31. Barton, D.H.R.; Shioiri, T.; Widdowson, D.A. Biosynthesis of terpenes and steroids. Part V. The synthesis of ergosta-5,7,22,24(28)-tetraen-3ß-ol, a biosynthetic precursor of ergosterol. J. Chem. Soc. C 1971, 1968-1974. [CrossRef]

32. Ericsson, D.C.B.; Ivonne, J.N.R. Sterol composition of the macromycete fungus Laetiporus sulphureus. Chem. Nat. Compd. 2009, 45, 193-196. [CrossRef]

33. Barrero, A.F.; Oltra, J.E.; Poyatos, J.A.; Jiménez, D.; Oliver, E. Phycomysterols and other sterols from the fungus Phycomyces blakesleeanus. J. Nat. Prod. 1998, 61, 1491-1496. [CrossRef] [PubMed]

34. Barrero, A.F.; Enrique Oltra, J.; Robinson, J.; Burke, P.V.; Jiménez, D.; Oliver, E. Sterols in erg mutants of Phycomyces: Metabolic pathways and physiological effects. Steroids 2002, 67, 403-409. [CrossRef]

35. Alcazar-Fuoli, L.; Mellado, E.; Garcia-Effron, G.; Lopez, J.F.; Grimalt, J.O.; Cuenca-Estrella, J.M.; Rodriguez-Tudela, J.L. Ergosterol biosynthesis pathway in Aspergillus fumigatus. Steroids 2008, 73, 339-347. [CrossRef] [PubMed]

36. Bode, H.B.; Bethe, B.; Höfs, R.; Zeeck, A. Big effects from small changes: Possible ways to explore Nature's chemical diversity. ChemBioChem 2002, 3, 619-627. [CrossRef]

37. Fakas, S.; Papanikolaou, S.; Batsos, A.; Galiotou-Panayotou, M.; Mallouchos, A.; Aggelis, G. Evaluating renewable carbon sources as substrates for single cell oil production by Cunninghamella echinulata and Mortierella isabellina. Biomass Bioenergy 2009, 33, 573-580. [CrossRef]

38. Meeuwse, P.; Klok, A.J.; Haemers, S.; Tramper, J.; Rinzema, A. Growth and lipid production of Umbelopsis isabellina on a solid substrate-Mechanistic modeling and validation. Process Biochem. 2012, 47, 1228-1242. [CrossRef]

39. Ratledge, C. Regulation of lipid accumulation in oleaginous microorganisms. Biochem. Soc. Trans. 2002, 30, 1047-1050. [CrossRef] [PubMed]

40. Economou, C.N.; Aggelis, G.; Pavlou, S.; Vayenas, D.V. Single cell oil production from rice hulls hydrolysate. Bioresour. Technol. 2011, 102, 9737-9742. [CrossRef]

41. Lamb, D.C.; Kelly, D.E.; Kelly, S.L. Molecular diversity of sterol $14 \alpha$-demethylase substrates in plants, fungi and humans. FEBS Lett. 1998, 425, 263-265. [CrossRef]

42. Bean, T.P.; Cools, H.J.; Lucas, J.A.; Hawkins, N.D.; Ward, J.L.; Shaw, M.W.; Fraaije, B.A. Sterol content analysis suggests altered eburicol 14 $\alpha$-demethylase (CYP51) activity in isolates of Mycosphaerella graminicola adapted to azole fungicides. FEMS Microbiol. Lett. 2009, 296, 266-273. [CrossRef] [PubMed]

43. Lamb, D.; Kelly, D.; Kelly, S. Molecular aspects of azole antifungal action and resistance. Drug Resist. Updat. 1999, 2, 390-402. [CrossRef] [PubMed]

44. Goad, J.L.; Akihisa, T. Analysis of Sterols; Blackie Academic \& Professional (Chapman \& Hall): London, UK, 1997; ISBN 978-94-010-7147-5.

45. Shirane, N.; Murabayashi, A.; Masuko, M.; Uomori, A.; Yoshimura, Y.; Seo, S.; Uchida, K.; Takeda, K. Effect on ergosterol biosynthesis of a fungicide, SSF-109, in Botrytis cinerea. Phytochemistry 1990, 29, 2513-2520. [CrossRef]

46. Shirane, N.; Takenaka, H.; Ueda, K.; Hashimoto, Y.; Katoh, K.; Ishii, H. Sterol analysis of DMI-resistant and -sensitive strains of Venturia inaequalis. Phytochemistry 1996, 41, 1301-1308. [CrossRef]

47. De Almeida, T.L.; Monteiro, J.A.; Lopes, G.K.P.; Chiavelli, L.U.R.; Santin, S.M.D.O.; da Silva, C.C.; Kaplum, V.; Scariot, D.B.; Nakamura, C.V.; Ruiz, A.L.T.G.; et al. Chemical study and antiproliferative, trypanocidal and leishmanicidal activities of Maxillaria picta. Quím. Nova 2014, 37, 1151-1157. 
48. Akihisa, T.; Kithsiri Wijeratne, E.M.; Tokuda, H.; Enjo, F.; Toriumi, M.; Kimura, Y.; Koike, K.; Nikaido, T.; Tezuka, Y.; Nishino, H. Eupha-7,9(11),24-trien-3ß-ol ("Antiquol C") and other triterpenes from Euphorbia antiquorum latex and their inhibitory effects on Epstein-Barr virus activation. J. Nat. Prod. 2002, 65, 158-162. [CrossRef] [PubMed]

49. Kaneshiro, E.S.; Amit, Z.; Swonger, M.M.; Kreishman, G.P.; Brooks, E.E.; Kreishman, M.; Jayasimhulu, K.; Parish, E.J.; Sun, H.; Kizito, S.A.; et al. Pneumocysterol [(24Z)-ethylidenelanost-8-en-3 $\beta$-ol], a rare sterol detected in the opportunistic pathogen Pneumocystis carinii hominis: Structural identity and chemical synthesis. Proc. Natl. Acad. Sci. USA 1999, 96, 97-102. [CrossRef]

50. Bok, J.W.; Lermer, L.; Chilton, J.; Klingeman, H.G.; Towers, G.H.N. Antitumor sterols from the mycelia of Cordyceps sinensis. Phytochemistry 1999, 51, 891-898. [CrossRef]

51. Aghaei, M.; Yazdiniapour, Z.; Ghanadian, M.; Zolfaghari, B.; Lanzotti, V.; Mirsafaee, V. Obtusifoliol related steroids from Euphorbia sogdiana with cell growth inhibitory activity and apoptotic effects on breast cancer cells (MCF-7 and MDA-MB231). Steroids 2016, 115, 90-97. [CrossRef]

52. Dong, H.; Gou, Y.L.; Kini, R.M.; Xu, H.X.; Chen, S.X.; Teo, S.L.M.; But, P.P.H. A new cytotoxic polyhydroxysterol from soft soral Sarcophyton trocheliophorum. Chem. Pharm. Bull. (Tokyo) 2000, 48, 1087-1089. [CrossRef]

53. Zovko Končić, M.; Ioannou, E.; Sawadogo, W.R.; Abdel-Razik, A.F.; Vagias, C.; Diederich, M.; Roussis, V. $4 \alpha$-methylated steroids with cytotoxic activity from the soft coral Litophyton mollis. Steroids 2016, 115, 130-135. [CrossRef] [PubMed]

54. Moghadam, M.H.; Firouzi, J.; Saeidnia, S.; Hajimehdipoor, H.; Jamili, S.; Rustaiyan, A.; Gohari, A.R. A cytotoxic hydroperoxy sterol from the brown alga, Nizamuddinia zanardinii. DARU J. Pharm. Sci. 2013, $21,24$. [CrossRef] [PubMed]

55. Pang, X.; Lin, X.; Wang, J.; Liang, R.; Tian, Y.; Salendra, L.; Luo, X.; Zhou, X.; Yang, B.; Tu, Z.; et al. Three new highly oxygenated sterols and one new dihydroisocoumarin from the marine sponge-derived fungus Cladosporium sp. SCSIO41007. Steroids 2018, 129, 41-46. [CrossRef] [PubMed]

56. Popova, M.; Trusheva, B.; Gyosheva, M.; Tsvetkova, I.; Bankova, V. Antibacterial triterpenes from the threatened wood-decay fungus Fomitopsis rosea. Fitoterapia 2009, 80, 263-266. [CrossRef]

57. Sharma, R.K.; Behari, M. Screening of the compound isolated from the leaves of Annona squamosa for antibacterial activity. Acta Cienc. Indica Chem. 1992, 18, 249-252.

58. Niedermeyer, T.H.J.; Lindequist, U.; Mentel, R.; Gördes, D.; Schmidt, E.; Thurow, K.; Lalk, M. Antiviral terpenoid constituents of Ganoderma pfeifferi. J. Nat. Prod. 2005, 68, 1728-1731. [CrossRef] [PubMed]

59. Smania, A., Jr.; Monache, F.D.; Smania, E.D.F.A.; Cuneo, R.S. Antibacterial activity of steroidal compounds isolated from Ganoderma applanatum (Pers.) Pat. (Aphyllophoromycetideae) fruit body. Int. J. Med. Mushrooms 1999, 1, 325-330. [CrossRef]

60. Sarker, S.D.; Nahar, L.; Kumarasamy, Y. Microtitre plate-based antibacterial assay incorporating resazurin as an indicator of cell growth, and its application in the in vitro antibacterial screening of phytochemicals. Methods 2007, 42, 321-324. [CrossRef]

(C) 2019 by the authors. Licensee MDPI, Basel, Switzerland. This article is an open access article distributed under the terms and conditions of the Creative Commons Attribution (CC BY) license (http://creativecommons.org/licenses/by/4.0/). 